\title{
The influence of parents socio-economic conditions on student achievement in junior high schools
}

\author{
Dewi Rahmawati Safitri ${ }^{1}$, Happy Fitria $^{2}$, Rohana Rohana ${ }^{2}$ \\ ${ }^{1}$ Sekolah Menengah Pertama Negeri 46 OKU, Indonesia \\ ${ }^{2}$ Universitas PGRI Palembang, Indonesia
}

\begin{tabular}{l} 
Article Info \\
\hline Article history: \\
Received Jul $16^{\text {th }}, 2021$ \\
Revised Aug $15^{\text {th }}, 2021$ \\
Accepted Aug $30^{\text {th }}, 2021$ \\
\hline
\end{tabular}

\section{Keyword:}

Parent social economics Student achievement

\begin{abstract}
The research aims to identify, describe, and analyze whether or not the influence of the socio-economic conditions of parents on student achievement in Junior High Schools in Kedaton Peninjauan Raya District. This type of research is quantitative research. Population in this research as many as 464 students. A research sample of around 216 students was established by using the sampling technique proportional random sampling using the formula of slovin $5 \%$ of significance. The technique of Data collection by using questionnaires and documentation. Then data analysis using linear regression analysis with SPSS program. The result showed that the socio-economic conditions of parents affect student achievement. This paper is expected to provide directions and solutions for educational institutions to carry out education properly and appropriately by following the environmental conditions of the community in improving the quality of education.
\end{abstract}

(C) 2021 The Authors. Published by IICET.

This is an open access article under the CC BY-NC-SA license

(https://creativecommons.org/licenses/by-nc-sa/4.0

\section{Corresponding Author:}

Safitri, D. S.

Sekolah Menengah Pertama Negeri 46 OK, Indonesia

Email: dewi.bta2205@gmail.com

\section{Introduction}

Learning achievement is something that cannot be separated from learning activities because learning activities are a process while learning achievement is the result of the learning process. This is by following the opinion of [1], "Student achievement is the result obtained in the form of impressions that result in changes in individuals as a result of learning". This is by following with the opinion of [2] which states "learning achievement is influenced by two factors, namely internal and external factors". One of the external factors that influence student achievement is family. Family is very closely related to student learning outcomes. [3] states that the family is the first educational environment because it is in this family that children first get education and guidance, while the main task in the family for children's education is to lay the foundation for moral education and religious life views.

Therefore, parents should realize that family education is very important. The school is advanced. The transition of informal education to formal institutions must require good cooperation between parents and teachers as educators to improve learning outcomes. Also, according to [4], based on several previous studies 
there several factors that affect learning achievement including education, employment, and parents' income. Hasbullah in [5], states "the family is the first educational environment because it is in this family that a child first gets education and guidance". Thus the family has an important role in education so that the family background must be considered so that educational success is achieved as much as possible. [6] states that children from middle and upper family backgrounds get more guidance and direction from their parents' Children with low economic conditions do not get guidance and direction from parents because their parents are more focused attention on how to meet daily needs.

The socio-economic condition of parents greatly affects student achievement, which requires support to support student learning. This is in by the opinion of [2] "the economic condition of the family is closely related to student learning outcomes, students who are learning besides having to fulfill basic needs such as food, clothing, health protection, and others", all must be considered so that the success of education achieved as much as possible. Everyone has different and stratified socioeconomic conditions. Some have high socioeconomic conditions, some are moderate and some are low. According to [7], socio-economic status comes from three words that have different meanings, namely status which is the placement of a person in a certain position, social is a set of rights and obligations that a person has as a social being, while economic means a household situation. Socioeconomic status is a description of the condition of a family or a person in society in terms of the social economy [5]. In contrast to states that the socioeconomic status of parents includes the level of parental education, parent's occupation, and parents' income [8]. States that income will affect a person's social status, besides that the level of parental education also affects learning achievement [9]. That there is a significant influence between the level of parental education and the level of parents' income on achievement. However, according to [10], "there are several factors that can determine the level of socioeconomic status including education level, type of work, income level, environmental conditions in which to live, ownership of wealth, and participation in group activities of the community.

In research, the socio-economic status of parents is related to the ability of parents to motivate them according to educational background, income, and occupation [11]. The results show that $7.61 \%$ of parents' socioeconomic status affects learning achievement. In research conducted also shows that there is a significant influence on the socio-economic conditions of parents on student achievement [12]. Gerungan says that with a sufficient economy, the material environment faced by children in it is wider, children will easily follow the learning process because all supporting infrastructure for the learning process can be fulfilled from their parents. Conversely, when the socioeconomic status of the family is low, the child will have difficulty following the learning process at school because the supporting facilities and infrastructure are not fulfilled by parents.

The results of observations made at State Junior High Schools in the entire District of Kadaton Peninajian Raya, there is a problem that student achievement is low. Besides, the income of the students 'parents is low because the majority of students' parents work as rubber farmers. Most parents are unable to provide learning facilities such as those that facilitate access to learning resources. Especially during the pandemic, students are required to study at home. The online learning process is carried out during the pandemic, students send assignments that they have done at home using the Android Mobile facilities and internet access or quotas.

\section{Method}

This research is an associative study using a quantitative approach to look for the influence of parents' socioeconomic conditions on learning achievement in SMP Negeri in Kedaton Peninjauan Raya distric's. the academic year 2020/2021. In this study there is one independent variable, namely the socioeconomic conditions of parents (variable X), and one dependent variable, namely student achievement (variable Y). According to [13], "data collection methods are the methods used by research tools to collect data". Data collection techniques in this study using a questionnaire and documentation. The questionnaire in this study is closed because the questions or statements have the answers available. So the respondent only has to choose the answer that has been provided according to the real conditions.

Furthermore, the respondents are provided with five alternative answers which are interval data. For the questionnaire on the socio-economic conditions of parents, the respondents were provided with five alternative answers. For the questionnaire on the socioeconomic conditions of the parents, the respondents were provided with answer choices $\mathrm{A}, \mathrm{B}, \mathrm{C}, \mathrm{D}$, and $\mathrm{E}$. Whereas for the learning motivation questionnaire, the respondents were provided with five alternative answers which were scaled interval data. Likert. Alternative answers consist of: Always, often, ever, sometimes, and never. In compiling the score using a Likert scale with two 
alternative statements, namely positive and negative. The subjects of this study were students of SMP Negeri Kedaton Peninjuan Raya District. The population was 464 students. The research sample was taken by using the purposive sampling technique with the Slovin formula with a critical value of $5 \%$. The sample consisted of 216 students from 3 schools, namely SMP Negeri 15 OKU, SMP Negeri 19 OKU, and SMP Negeri 46 OKU.

Tabel $1<$ Sample>

\begin{tabular}{llc}
\hline No. & School Name & Total \\
1. & SMP Negeri 15 OKU & 118 student \\
2. & SMP Negeri 19 OKU & 69 student \\
3. & SMP Negeri 46 OKU & 29 student \\
Total & & 216 student \\
\hline
\end{tabular}

The research data were obtained using questionnaires and documentation. The questionnaire is used to determine the parents' socioeconomic conditions. Meanwhile, documentation is used to determine student achievement. Documentation is a method or method of collecting data from documents (certain items) such as books, magazines, regulations, meeting minutes, daily notes and so on. The use of documentation in this study was to obtain data on the number of students and data on student achievement [13]. The instrument used has gone through the validation process and the reliability obtained from the trial. The data analysis process in this research is by tabulating the data for each variable. After that, the calculation of assumption tests and hypothesis tests is carried out with the help of the SPSS V 21 program.

\section{Results and Discussions}

Based on the results of data processing that was successfully collected from 216 students. The mean (average value) as seen from the descriptive statistical table is 75.17 . The socioeconomic conditions of parents including education, employment, income, living conditions, the wealth owned, and participation in group activities are categorized as low with a percentage of $46 \%$ being at a low level. When viewed from each indicator of the level of education of the students' parents, employment and income are as follows:

Tabel $2<$ Parents Education $>$

\begin{tabular}{lcc}
\hline Education & Frequency & Percent \\
SD & 30 & $13,9 \%$ \\
SMP & 63 & $29,2 \%$ \\
SMA & 119 & $55,1 \%$ \\
Diploma / S1 & $\mathbf{4}$ & $\mathbf{1 , 9 \%}$ \\
\hline
\end{tabular}

Tabel $3<$ Parents' Job $>$

\begin{tabular}{lcc}
\hline Profession & Frequency & Percent \\
Farmer & 213 & $98,6 \%$ \\
Government Employes & 3 & $1,4 \%$ \\
\hline
\end{tabular}

Tabel 4 <Income of Parents>

$\begin{array}{lcc}\text { Income } & \text { Frequency } & \text { Percent } \\ <\text { IDR } 1.000 .000 ; & 50 & 23,1 \% \\ 1.000 .000-2.000 .000 & 160 & 74,1 \% \\ 2.000 .000-3.000 .000 & 6 & 2,8 \%\end{array}$

The education of the parents of the students is quite sufficient because $55.1 \%$ are high school graduates. The employment and income indicators are in a low category. The majority of parents work as farmers with a percentage of $98 \%$. Parents' income is low with total income ranging from IDR $1.000 .000-\mathrm{Rp} 2.000 .000$ with a percentage of $74.1 \%$.

Meanwhile, the regression analysis test results from the coefficient table show the results of hypothesis testing with the $t$-test where it is known that the $t$ value is 6.214. Then the value of $t$ test is compared with the value of $t$ tabel (6.214) $>t$ tabel 1.960 then Ho is rejected and Ha is accepted, meaning that it is significant. So the results of the study show that the socio-economic conditions of parents have a significant effect on student 
achievement. The value of the contribution of parents' socioeconomic conditions to learning achievement is $15.3 \%$, while the rest is influenced by other factors.

The results of this study indicate a significant influence of the socio-economic conditions of parents on student achievement, meaning that the economic conditions of parents increase, the learning achievement will increase. So as a whole the socio-economic conditions of parents facilitate the teaching and learning process at school. This can be seen from the fulfillment of children's needs. Parents can meet the needs and learning facilities of children, with the fulfillment of learning needs and facilities, students become enthusiastic in participating in learning at school so that student learning achievement increases.

\section{Conclusions}

Based on data analysis and hypothesis testing, it can be concluded that there is a significant influence on the socio-economic conditions of parents on student achievement in SMP Negeri in Kedaton Peninjauan Raya District.

\section{References}

Aunurrahman. 2011. Belajar dan Pembelajaran. Bandung: Alfabeta

Arifin, M. 2008. Hubungan Timbal Balik Pendidikan Agama. Jakarta: Bulan Bintang

Barnawi dan Arifin, M. 2012. Etika dan Profesi Kependidikan. Jogjakarta: Ar-ruzz. Media.

Daulay, H.P. 2009. Dinamika Pendidikan Islam di Asia Tenggara. Jakarta: Asdi Mahasatya

Hadiyanto. 2004. Mencari Sosok Desentralisasi Manajemen Pendidikan di Indonesia. Jakarta: Rineka Cipta

Herabudin. 2009. Administrasi dan Supervisi Pendidikan. Bandung : Pustaka Setia

Kristiawan, M dan Rahmat, N. 2018. Peningkatan Profesionalisme Guru Melalui Inovasi Pembelajaran. Jurnal Iqra': Kajian Ilmu Pendidikan, 3(2)

Kadarisman, M. 2013. Manajemen Pengembangan Sumber Daya Manusia. Jakarta: Rajawali

Muslim, B; Harapan, E dan Kesumawati, N. 2020. Kepemimpinan Kepala Sekolah Dalam Meningkatkan Mutu Pendidikan di SMA Negeri 1 Indralaya Selatan. Jurnal Intelektualita, Keislaman, Sosial dan Sains, $9(1)$

Mulyasa, E. 2009. Menjadi Kepala Sekolah Profesional. Bandung: PT. Remaja Rosdakarya

Soekanto, S. 2007. Sosiologi Suatu Pengantar. Jakarta : PT Raja Grafindo Persada

Sugiyono. 2019. Metode Penelitian Kuantitatif Kualitatif. Bandung: Alfabeta.

Wahjosumidjo. 2013. Kepemimpinan Kepala Sekolah. Jakarta: PT. Raja Grafindo Persada \

Yahya, Y. 2006. Pengantar Manajemen. Yogyakarta: Graha Ilmu 